\title{
Using the sun in own favor: a study about energy efficiency in a chemical industry
}

Gustavo Brito Badico , Etienne Cardoso Abdala1 ${ }^{1}$ Lucas Conde Stocco ${ }^{1}$, André Selistre Donega², Luciana Oranges Cezarino ${ }^{1}$

'School of Business and Management, Federal University of Uberlandia - UFU, Uberlândia, Brazi

${ }^{2}$ School of Economics, Business Administration and Accounting at Ribeirao Preto, University of São Paulo - USP, Ribeirão Preto, Brazi

How to cite: Badico, G.B., Abdala, E.C., Stocco, L.C. et al. (2020), “Using the sun in own favor: a study about energy efficiency in a chemical industry", Brazilian Journal of Operations \& Production Management, Vol. 17, No. 2, e2020898. https://doi.org/10.14488/BJOPM.2020.023.

\section{ABSTRACT}

Goal: This paper aims to analyze the economic feasibility of the inclusion of solar energy boiler in the production process in a chemical industry.

Design/Methodology/ Approach: The research method used was documentary analysis in organizational reports, interviews with suppliers and observation. For the feasibility analysis of the solar energy inclusion project, Payback, Internal Rate of Return (IRR) and Net Present Value (NPV) calculations were performed.

Results: Results show that the adequacy of the production system from the use of solar energy contributes to the three areas of the Triple Bottom Line (TBL), that is, economical because its contributions to the organization's long-term cost reduction, social by ensuring greater safety to workers around the boiler and environmental by reducing the rate of greenhouse gases emissions from burning fossil fuels.

Limitations of the investigation: The paper limitations are related to the fact that the study was made from data collected in a single organization from chemical industry sector to trace the feasibility of the project, this fact does not allow us to assume generalizations to other companies in the sector.

Practical implications: The study shows the importance of adopting new production systems based on cleaner energies and what contributions can be achieved on sustainability by organizations, society and the environment.

Originality/Value: By analyzing the feasibility of adapting a production system to a chemical industry, the study contributes to the field of research on environmental management and sustainability.

Keywords: Environmental Management; Corporate Responsibility; Solar Energy; Sustainable Production.

\section{INTRODUCTION}

The population rate growth was responsible for generating uncontrollable resource extraction from environment. For a long time, it has not become crucial on a global perspective, however, the population began to increase, and the production had to be scaled by removing more materials from the environment, causing environmental degradation. Therefore, the pollution levels increased in a similar manner to environmental degradation due to production processes (Cherniwchan, 2012).

Financial support: None.

Conflict of interest: The authors have no conflict of interest to declare.

Corresponding author: lucasstocco@hotmail.com

Received: 23 Sep 2019.

Approved: 09 May 2020.

Editor: Osvaldo L. G. Quelhas. 
Concerns about sustainable development have emerged from the major importance in response to impacts caused by human activity given the finitude of natural resources. (Haas et al., 2015). This brings us to the idea of sustainable development as one in which meeting the needs of the present generation does not undermine the needs of future generations (Brundtland, 1987).

Organizations observing this new tendency to apply sustainability concepts in their processes and worrying about the role they should play has sought approaches that contribute to minimizing the negative externalities arising from their activities. Among several approaches, one of the most accepted by companies is the tripod of sustainability theory points to three dimensions to achieve sustainability: environmental, social and economic, the Triple Bottom Line (TBL) (Elkington, 1994).

Environmental management becomes a necessity to meet legislation and regulatory pressures, but can also be seen as a strategy to work as a differential for competitiveness, especially in a competitive sector like chemical industries, which is negatively seen by society due to its "social and environmental impact (health and safety risks, large-scale pollution" (Verboven, 2011). Thus, an opportune context is identified, which requires a feasibility study of environmental management projects for these companies contributing to reduce environmental harm.

The chemical industry represents a sector that contributes to various economic and consumer activities. The sector is also characterized by large, capital-intensive investments with long maturities and long service life (Associação Brasileira da Indústria Química, 2010). The chemical sector in Brazil has a negative trade balance, this history has been aggravated by the increase of imports and productive transfer to foreign industries (Price Waterhouse Coopers, 2013). These difficulties can be understood as opportunities to generate significant development of the sector through investments and government incentives as it has large companies operating in Brazil (Instituto Latino-Americano de Estudos Socioeconômicos, 2014).

One of the capable areas of increasing the competitiveness gain by companies in this sector would be the investment in the environmental projects, especially projects that enable the improvement of processes and reduction of the environmental impacts resulting from their productive activities. For this reason, the following research problem can be raised: how feasible is the deployment of solar energy in the boiler process in a chemical industry?

To answer this research problem, the objective of the present work is to analyze the economic feasibility of a solar energy boiler implementation in the production process of a chemical industry. The defined methodological approach is the qualitative descriptive type, which seeks to analyze the feasibility of implementing a solar energy supply system. For this, we used documentary research, interviews with suppliers' managers and observation, with subsequent elaboration of viability calculations of the proposed project, using cash flow, Payback, Internal Rate of Return (IRR) and Net Present Value (NPV).

The paper is organized as follows. The following section presents the theoretical framework that seeks to present the contributions of studies to the area of environmental management. The third section presents the methodological path defined for the research. The following section presents the results obtained, followed by the final considerations, study limitations and indications for future research.

\section{LITERATURE OVERVIEW}

\subsection{Environmental management}

Since the beginning of the human existence, nature has been a source for ensuring the production of goods and services in order to guarantee the quality life of all people on Earth. The problem was intensified when production began to gain large scale and resources had to be removed in exacerbated quantities and with great agility, leaving behind waste negative impacts. The production and consumption continue to grow and are increasingly being perceived as threats to the livelihoods of many people of our generation and future generations (Barbieri, 2007). 
As production intensifies to supply a large and increasing consumption demand, the planet suffers scarcity of resources concerning organizations to think a strategy manners to return them to the environment, however, due to inability to decompose and turn into chemical elements capable of absorption by other living beings, the residues originated by companies become principally pollution (Barbieri, 2007).

Condensing the discussions, the concept of environmental management brings together the actions that society imposes for the search for braking and reducing the negative impacts caused by human actions. The concept of environmental management, in the words of Tolba (1982), is not the management of the environment, but the redirection of human activities that significantly impact the environment, aiming to reduce it. The main objective of environmental management is to meet the needs of human beings respecting the potential and constraints of environmental systems on a projection of time that is considered sustainable.

Barbieri (2007) cites the importance of taking care of these resources that do not have facility to renew itself and points out the companies and their productions as major agents of possible changes.

Dealing with production processes, environmental issues are becoming increasingly at key points along the economic and technological aspects. When choosing an environmentally responsible manufacturing, we need to re-evaluate the processes and continuously improve interactions between activities, products and services to the environment (Ometto et al., 2007). A company that ignores the reduction of its negative impacts on the environment is bound to loss of consumer market share, and subject to legal penalties. This means that environmental issues are not only technical in nature, turning into key points of business strategy, creating opportunities for businesses with profits as central goals (Doyle and Von Windheim, 2015).

In 2016, brazilian chemical industry ranked 6 th by revenues which represents an amount of US $\$ 5.197,6$ billion and corresponds to $2 \%$ of the global total. In contrast, in order to achieve the results, this sector is considered as energy intensive, having required the equivalent to 266.1 tons in the same year. As a result, this high energy consumption is mainly responsible for the product price at final consumer product (Confederação Nacional da Indústria, 2010). For the implementation of a project that aims to save energy from sunlight, in addition to receiving the company's economic resources without long term, presents itself as an advantage in society with less perceived direct financial impact considering this in an environment where everyone benefits from the lower generation of greenhouse gases.

\subsection{Feasibility analysis: payback, IRR and NPV}

Ross et al. (2008) define the payback period as "the time required to recover the initial investment". Assaf Neto (2008) also adds that recovery is done through "net incremental benefits box promoted by the investment". By knowing how much the present value of each of the entries of cash flow represents, we will be able to know the exact period in which the investment will be balanced (Ross et al., 2008)

The word "cost" generally refers to the disbursement, what may be seen under a negative perspective. But if the opportunity cost is portrayed as an investment, it can be seen as defined by Parkin (2005): "the highest value alternative that we give up to get something" or to the "next-best alternative" (Miller, 2001).

The Net Present Value (NPV) is considered a sophisticated technique that considers the value of money over time or, in other words, the capital budget is contemplated (Gitman, 2007). This calculation is obtained by discounting the cash flows incurred over the useful life of the project, which makes it possible to schedule project activities so that NPV is maximized (Creemers, 2018). This concept is structured on the assumption that the variation on the present value and future benefits of a project cost is zero (Basher and Raboy, 2018; Chen et al., 2018).

The Internal Rate of Return, according to Assaf Neto (2008) shows that the inputs and outputs provided for cash are usually matched at baseline, one in which the disbursement of the investment takes place. Method that brings the future cash flow to present value, is the 
profitability of the project expressed in terms of interest rate compounded periodically equivalent. The IRR is therefore the rate that allows the NPV equal to zero, that is, the rate of return at the economic balance of the project (Ross et al., 2008). Additionally, it is about a powerful indicator through which sustainable effectiveness can be measured, once it analyzes, among the others, the feasibility to energy efficiency through from implementation of new technologies.

\section{METHOD}

Overall, the study aims to analyze the economic feasibility of the inclusion of solar energy in the production process in a chemical industry. For this we consider the research as qualitative and descriptive, where document analysis and financial mathematic calculations were used. Qualitative research is justified because the use of this approach allows the researcher to better understand the plurality of relationships between stakeholders (Flick, 2009). Descriptive studies can also conduct experiments aimed interpret and evaluate application of some predetermined factors, or evaluate existing findings (Vergara, 2004).

Based on these concepts, we can conclude that the present paper is a qualitative study in which was not used statistical methods to reach conclusions, but it focused in describing the highlighted phenomenon. It can, therefore, be assumed that the results found in a qualitative research can be presented separately as well as in conjunction with quantitative data (Patton, 2005).

Data collection for research was made from information acquired from managers of the chemical industry and suppliers of material for installation of solar energy systems, as well as documentary analysis from organizational reports and observation. The documental analysis of various types can be used, in order to provide the researcher with additional data for a better understanding of the problem investigated (Godoy, 1995). We also used a process of observation, on which the researchers could experience the organizational context, truly understanding the complexity of the problem in focus, generating several insights for increased competence (Zanelli, 2002).

For the elaboration of viability calculations of the proposed project, we applied the cash flow, Payback, Internal Rate of Return (IRR) and Net Present Value (NPV), concepts to a 25 years period.

\section{RESULTS AND DISCUSSION}

Data collection was based on organizational reports analysis, so that the financial analysis process and the investment capacity available to the organization to assess the conditions for implementation of possible changes could be initiated.

The research object of this study is constituted by a consolidated organization of the Chemical Industry Sector and with important participation in the regional market, located in the Triangulo Mineiro region of Brazil that provides products for several areas such as: industrial; hospitals, automotive; hygiene, among others.

During a week, a search was carried out in the company's file seeking the invoices of the gas supplier and later the information was tabulated to check the cash disbursements that the company performed.

To be performed the choice by solar panels, began a mapping of potential suppliers in the city of Uberlandia and Triangulo Mineiro region in search of budgets and more technical details about the solution.

For project elaboration there are needed forty-five heaters "Aquakent AKC 25". This system consists of collectors mounted parallel to one another and a low power pump which circulates water between collectors and tanks. The equipment is installed on the roof of the property (which has a large area in square meters, due to the length of the upright machines and inventories). Then it sets the value of the initial investment requirements as shown by Table 1 . 
Table 1. Disbursement of the initial investment.

\begin{tabular}{cc}
\hline Item description & Value (BRL) \\
\hline Heaters 45 “Aquakent AKC 25" and 25 vacuum glass tubes & $130,000.00$ \\
\hline Installation Hydraulic / Pipelines & $1,220.00$ \\
\hline Connections and Showers & 342.00 \\
\hline Pumps & 425.00 \\
\hline Labor (masons and plumbers) & $2,518.00$ \\
\hline Total Initial investment & $134,505.00$ \\
\hline
\end{tabular}

Source: elaborated by the authors.

As can be seen, the initial investment is made for the purchase of heaters and vacuum glass tubes and all the expenses that will be incurred for the technology to be installed and the structure is adapted to receive it. Once we have determined how much should be paid as initial investment, we can start a study on the projection of cash flows that will occur after the investment that has been realized.

To determine the future cash flow, it is necessary to analyze how much the company would no longer spend on the purchase of liquefied petroleum gas, after all, avoid cash disbursement is a way to gain within the finance concepts (Assaf Neto, 2008).

This determination of how much is paid with gas, was made a document analysis reports produced by the company boiler technician, including information regarding the boiler usage time, the amount of gas used, medium pressure, and also analysis of past invoices in gas purchases, obtaining information on the amount paid for gas, effectively, as well as frequency of purchases.

The first step was to then calculate the average value of the invoices. Therefore, it was possible to obtain an average value of $R \$ 6,898.90$ per invoice. Then, these values are added together and divided by the amount of incurred claims. The result was that each invoice provides raw material for 38.2308 days of boiler operation. With this information calculated and knowing the average value of invoices, it was possible to determine the average amount spent each day with the bulk gas. The result of this operation was $R \$ 180.45$. This means that, on average, to operate the boiler per day is spent $R \$ 180.45$.

This value is the input box designed in case of replacement of the power source. However, as above, the solar panels technology would not be able to turn water into steam and, according to information from suppliers, would remain a disbursement of $9.10 \%$ of what is done today for the operation to work, that is, to the water from the solar panels increases a few degrees and turns into steam.

Thus, it is established that the cash inflow to be projected cash flow is only $90,91 \%$ of that before would gain, because the rest is still being spent on buying gas to supplement the operation of the plates.

This means that the new daily cash inflow will be $R \$ 164,05$, or $R \$ 16,40$ per day will be spent on liquefied petroleum gas. The total that was spent on invoices, a portion will be kept buying small quantities and most of the remainder will be saved fact, this means it will be entering the cash flow.

As the focus of the company's project will be fully equity funded to determine opportunity costs, it is necessary to know what type of investor the business owner and it has been found that the individual is a conservative investor with a fixed income background. After determining the type of investor, it was possible to conduct a market research to determine which investments were available for conservative profiles, i.e. fixed income as savings, Certificado de Depósito Bancário (CDB), Letra de Crédito Imobiliário (LCl), among others, as presented by Table 2 .

Table 2. Investment Alternative sources

\begin{tabular}{cc}
\hline Investment & Monthly fee (\%) \\
\hline BB CDB Pre & 0.58 \\
\hline Savings account & 0.59 \\
\hline LCI & 0.61 \\
\hline Treasury Direct & 0.64 \\
\hline BB CDB DI Partnership & 0.67 \\
Itaú CBD & 0.95 \\
\hline
\end{tabular}

Source: Banco do Brasil; Banco Itaú. 
As found in theory, it is necessary that the highest return on investment was used as a criterion to determine the opportunity cost and this investment is a CDB Itaú Bank, which offers a rate of return of $0.95 \%$ per month, that is to invest in solar heating project, the investor will give up to gain $0.95 \%$ per month, making this your opportunity cost. However, this value is raw and needs to be transformed to the actual return, this means that you need to discount inflation and income tax to be paid on profitability. The current inflation is $6.41 \%$ per annum. then performed the conversion rate for this month $0.85 \%$ per month.

We still must discount the Income Tax (IR) IN an investment with a useful life of 25 years, it uses the rate of $15 \%$ (for applications up to two years). As the cash flow is annual, it took transform the monthly fee in annual determining that the opportunity cost is of 9,02\% annually

However, it is known that the useful life of the project in question is 25 years, according to data reported by the solar panel supplier. Therefore, it is necessary to transform the average daily amount spent by the average annual amount spent. Then it goes to an average annual amount spent on the boiler process of $\mathrm{R} \$ 59.058,00$. This is the amount that will be saved annually due to the implementation of solar panels. With this information, we can determine the projected cash flow of the investment once the initial investment has been calculated and the projected inputs are now known. To calculate the payback is necessary to know the cumulative value of cash flows, i.e. the balance of the year zero over the year one more year two and so on.

With this result, we can define the exact moment of the return occurrence, turning 0.7721 in months, reaching a score of 9.2652 and 0.22652 later, turning into days, obtaining 7.956. To calculate Net Present Value or NPV, we used the same discounted cash flow as was done in the previous section. The values in Brazilian Real (BRL) of these operations are presented in Table 3.

Table 3. Cash Flow, NPV e Payback

\begin{tabular}{cccc}
\hline Period & Value (BRL) & PV rate of 9,023 (BRL) & Accumulated (BRL) \\
\hline 0 & $134,505.00$ & & $(134,505.00)$ \\
\hline 1 & $59,058.00$ & $54,170.22$ & $(80,334.78)$ \\
\hline 2 & $59,058.00$ & $49,686.97$ & $(30,647.81)$ \\
\hline 3 & $59,058.00$ & $45,574.76$ & $14,926.95$ \\
4 & $59,058.00$ & $41,802.88$ & $56,729.83$ \\
\hline 5 & $59,058.00$ & $38,343.18$ & $95,073.01$ \\
\hline 6 & $59,058.00$ & $35,169.81$ & $130,242.82$ \\
\hline 7 & $59,058.00$ & $32,259.07$ & $162,501.89$ \\
\hline 8 & $59,058.00$ & $29,589.23$ & $192,091.12$ \\
\hline 9 & $59,058.00$ & $27,140.36$ & $219,231.48$ \\
\hline 10 & $59,058.00$ & $24,894.16$ & $244,125.64$ \\
\hline 11 & $59,058.00$ & $22,833.86$ & $266,959.50$ \\
\hline 12 & $59,058.00$ & $20,944.08$ & $287,903.58$ \\
\hline 13 & $59,058.00$ & $19,210.69$ & $307,114.27$ \\
\hline 14 & $59,058.00$ & $17,620.77$ & $324,735.04$ \\
\hline 15 & $59,058.00$ & $16,162.44$ & $340,897.48$ \\
\hline 16 & $59,058.00$ & $14,824.79$ & $355,722.27$ \\
\hline 17 & $59,058.00$ & $13,597.86$ & $369,320.13$ \\
\hline 18 & $59,058.00$ & $12,472.47$ & $381,792.60$ \\
\hline 19 & $59,058.00$ & $11,440.22$ & $393,232.82$ \\
\hline 20 & $59,058.00$ & $10,493.40$ & $403,726.22$ \\
\hline 21 & $59,058.00$ & $9,624.94$ & $413,351.16$ \\
\hline 22 & $59,058.00$ & $8,828.36$ & $422,179.52$ \\
\hline 23 & $59,058.00$ & $8,097.70$ & $430,277.22$ \\
\hline 24 & $59,058.00$ & $7,427.52$ & $6,517.54$ \\
\hline 25 & $59,058.00$ & $6,812.80$ & \\
\hline
\end{tabular}

Source: elaborated by the authors. 
With the discount value for each period in which the investment will be bringing back it becomes possible to start a following NPV calculation formula. The NPV found is $\mathrm{R} \$ 444,517,518$. All calculations brought an IRR equal to $43.90 \%$. To determine whether this is a good value, it must be compared with the opportunity cost. If the IRR is greater than the rate should be an accepted project, otherwise, refuses investment.

Therefore, since $43,903>9,023$ at many times, we can say that the IRR method is also suitable for the company that the project is accepted.

\section{FINAL CONSIDERATIONS}

Widely discussed, Sustainability aims to aware and encourage society in order to "meet the needs of the present without compromising the ability of future generations to meet their own needs" (Brundtland, 1987). As mentioned by Bansal and DesJardine (2014), companies - as well as people - should progressively develop skills that fulfill their short-term financial expectations without compromising their permanence in the market through actions that balance economic, societal and ecological systems. In addition, organizations should provide unintentional work for community resulting in a responsible management that increases what Porter and Kramer (2006) call as "shared value" which justifies how favorable Corporate Social Responsibility (CSR) is to the various stakeholders.

The chosen manufacturing process is the boiler of the mining industry that chemical gases used for environmental damage, even with the legal safety conditions met. The solution involved replacing a large majority of the boiler energy source, reducing the need of gas due to water already at very high temperatures due to deployment of solar panels on the roof of the company. It was then defined as the initial investment would be through a market survey of suppliers. Through an analysis of tax documents as it has been historically been spent on purchases of gas it was discovered as could be spared if the demanded amount of gas to be reduced. Thus, this investment has been designed the cash flow calculated and deducted from the investment payback, NPV and IRR of the same.

The project with a Payback in 2 years 9 months and 7 days is accepted by the company to be less than five years, the acceptable value for investment longer life than 20 years. Positive NPV of R $\$ 444,517,518.00$ also makes the investment viable, and the IRR of $43.90 \%$, value greater than the opportunity cost.

The results presented achieve the objectives proposed in this study, since the sustainable basis of this project can be deployed, respecting all the tripod of sustainability: the economic dimension financial ratios also contribute to reducing the company's disbursements in the social dimension, ensures greater safety people around the boiler and mainly from the network operator and the environmental dimension is able to reduce the impact on the ozone layer due to the reduction of emission of greenhouse gases.

Future research can be directed to sector viability analysis considering the adequacy of production systems and installation of photovoltaic panels for boiler heating, as well as making a comparative analysis between different heating systems and their contribution to reducing environmental impacts.

The paper limitations are related to the fact that the study was made from data collected in a single organization from chemical industry sector to trace the feasibility of the project, this fact does not allow us to assume generalizations to other companies in the sector. Also, by studying the feasibility of applying solar panels by the organization, it cannot be assumed that this energy source is the most advantageous depending on the organization's investment capacity and financial health.

\section{REFERENCES}

Associação Brasileira da Indústria Química - ABIQUIM (2010), Pacto Nacional da Indústria Química: Relatório. Abiquim, São Paulo. available at: http://canais.abiquim.org.br/pacto/Pacto_Nacional_Abiquim.pdf (accessed August 2019). 
Assaf Neto, A. (2008), Finanças corporativas e valor. Atlas, São Paulo.

Bansal, P. and DesJardine, M.R. (2014), "Business sustainability: It is about time", Strategic Organization, Vol. 12, No. 1, pp. 70-8. http://dx.doi.org/10.1177/1476127013520265.

Barbieri, J.C. (2007), Gestão Ambiental Empresarial - Conceitos Modelos e Instrumentos. Saraiva, São Paulo.

Basher, S.A. and Raboy, D.G. (2018), "The misuse of net present value in energy efficiency standards", Renewable \& Sustainable Energy Reviews, Vol. 96, pp. 218-25. http://dx.doi.org/10.1016/j.rser.2018.07.047.

Brundtland, G.H. (1987), Report of the World Commission on Environment and Development: Our common future, United Nations, New York.

Chen, C., Lu, Y. and Banares-Alcantara, R. (2018), "Direct and indirect electrification of chemical industry using methanol production as a case study", Applied Energy, Vol. 243, No. 1, pp. 71-90.

Cherniwchan, J. (2012), "Economic growth, industrialization, and the environment", Resource and Energy Economics, Vol. 34, No. 4, pp. 442-67. http://dx.doi.org/10.1016/j.reseneeco.2012.04.004.

Confederação Nacional da Indústria - CNI (2010), Oportunidade de eficiência energética para indústria. Brasilia. available at: http://www.portaldaindustria.com.br/publicacoes/2012/9/oportunidadesdeeficiencia-energetica-para-a-industria/\#sumario-visao-institucional\%20 (accessed August 2019).

Creemers, S. (2018), "Maximizing the expected net present value of a project with phase-type distributed activity durations: An efficient globally optimal solution procedure", European Journal of Operational Research, Vol. 267, No. 1, pp. 16-22. http://dx.doi.org/10.1016/j.ejor.2017.11.027.

Doyle, M.W. and Von Windheim, J. (2015), "Environmental Management Strategy: four forces analysis", Environmental Management, Vol. 55, No. 1, pp. 6-18. http://dx.doi.org/10.1007/s00267-014-0389-5. PMid:25331643.

Elkington, J. (1994), "Towards the sustainable corporation: win-win-win business strategies for sustainable development", California Management Review, Vol. 36, No. 2, pp. 90-100. http://dx.doi.org/10.2307/41165746.

Flick, U. (2009), Introdução à pesquisa qualitativa, Artmed, Porto Alegre.

Gitman, L.J. (2007), Financial Management Principles, Pearson, São Paulo.

Godoy, A.S. (1995), "Introdução à pesquisa qualitativa e suas possibilidades", Revista de Administração de Empresas, Vol. 35, pp. 65-71. http://dx.doi.org/10.1590/S0034-75901995000400008.

Haas, W. Krausman, F. Wiedenhoer, D. \& Heinz, M. (2015), How circular is the global economy? An assessment of material flows, waste production, and recycling in the European Union and the world in 2005, Journal of Industrial Ecology, Vol. 19, No. 5, pp. 765-77.

Instituto Latino-Americano de Estudos Socioeconômicos - ILAESE (2014), "Economic Environment, Estudual Seminar: The Chemical Industry in $S P^{\prime \prime}$, available at: http://www.ilaese.org.br/wpcontent/uploads/2013/03/a-industria-quim\%C3\%ADca-no-Brail-em-2013-por-Eric-Gil.pdf (accessed August 2019).

Miller, R.L. (2001), Economics today, Addison Wesley Longman, Inc., Boston, MA

Ometto, A.D., Souza, M.P. and Son, A.G. (2007), "Environmental management in production systems", Magazine Research and Development Production Engineering, Vol. 6, pp. 22.

Parkin, M. (2005), Economics. Addison Wesley Longman, Inc., Boston, MA.

Patton, M.Q. (2005), Qualitative Research: Encyclopedia of Statistics in Behavioral Science, John Wiley \& Sons, Ltd, Chichester, pp. 1633-36.

Porter, M.E. and Kramer, M.R. (2006), "Strategy and Society: The Link between competitive advantage and corporate social responsibility", Harvard Business Review, Vol. 84, No. 12, pp. 78-92. PMid:17183795.

Price Waterhouse Coopers - PWC (2013), "Indústria Química no Brasil: um panorama do setor", available at: https://www.pwc.com.br/pt/publicacoes/setores-atividade/assets/quimico-petroquimico/2013/pwcchemicals-port-13.pdf (accessed August 2019).

Ross, S.A., Westerfield, R.W. and Jordan, B.D. (2008), Princípios da administração financeira, Atlas, São Paulo.

Tolba, M.K. (1982), Development without destruction: Involving environmental perceptions, Tycooly International Publishing, Dublin, Ireland. 
Verboven, H. (2011), "Communicating CSR and Business identity in the chemical industry through mission slogans", Business Communication Quarterly, Vol. 74, No. 4, pp. 415-31. http://dx.doi.org/10.1177/1080569911424485.

Vergara, S.C. (2004), Projetos e Relatórios de Pesquisa em Administração, 5th ed., Atlas, São Paulo.

Zanelli, J.C. (2002), "Pesquisa qualitativa em estudos da gestão de pessoas", Estudos de Psicologia, Vol. 7, No. Spe, pp. 79-88. http://dx.doi.org/10.1590/S1413-294X2002000300009.

Author contributions: An equal contribution was provided by all the authors to the elaboration of the present article. 